\title{
Conditional Payments and Insolvency - The Quistclose Trust
}

\author{
Gerard McCormack*
}

It is axiomatic that assets which form the subject-matter of a trust do not constitute part of the property of an insolvent available for distribution among the insolvent's creditors. Persons responsible for administering the affairs of insolvents take the property of the insolvent subject to equities. One such equity that must be recognised and upheld is the interests of beneficiaries under a trust where the insolvent holds the bare legal title. In this article the applicability of the doctrine of trusts in the realm of conditional payments will be considerd. If a lender lends money on condition that it is used for a particular purpose and/or paid back out of a particular fund, or if a purchaser pays in advance on condition that the money is used to provide something he wants, to what extent can the lender or payer enforce the conditional agreement?' There is something of an analogy with prepayments in sale of goods situations. It is possible for a seller of goods to retain title to the goods notwithstanding delivery of the goods to the buyer until the goods have been paid for or some other condition has been fulfilled. Conditional loans or payments are usually discussed under the rubric of the Quistclose trust and it is perhaps convenient to continue this classification. ${ }^{2}$

\section{The Quistclose Trust}

The locus classicus is Barclays Bank Ltd. v. Quistclose Investments Ltd. ${ }^{3}$ This is a case where Quistclose lent a company, Rolls Razor Ltd., some $£ 210,000$ to allow Rolls Razor to pay a dividend it had already declared. Rolls Razor sent the money to its bank, asking it to pay it into a separate dividend account and stating that the

\section{* School of Law, The University of Essex}

1. The link between reservation of title clauses in sales of goods and conditional loans or payments has not always been borne in mind when one or other of the two phenomena have been examined. However, the two are brought together in the excellent article by Goodhart and Jones, "The Infiltration of Equitable Doctrine into English Commercial Law" (1980) 43 M.L.R. 489. For a comprehensive examination of reservation of title clauses see McCormack, Reservation of Title (2nd. ed., 1995). See also Priestley, "The Romalpa Trust and the Quistclose Trust'" in P.D. Finn ed., Equity in Commercial Relationships (1987); Milman and Durrant, Corporate Insolvency Law and Practice (2nd. ed., 1994), Chapter 8; M. Bridge, (1992) 12 O.J.L.S. 333 and C.E.F. Rickett, (1991) 107 L.Q.R. 608.

2. Some would argue however that the Re Kayford Ltd. [1975] 1 W.L.R. 279 line of authorities are not true examples of the Quistclose trust properly so called.

3. [1970]A.C. 567 . 
money was to be used only to pay the dividend. But before the dividend could be paid Rolls Razor went into voluntary liquidation, leaving Quistclose and the bank to dispute ownership of the $£ 210,000$. The company's bank claimed the right to set off the $£ 210,000$ credit against a debit balance in another account.

The claim failed. The money was held to be impressed with a trust in favour of Quistclose should the primary purpose of the payment fail. Lord Wilberforce said that the mutual intention of Quistclose and of Rolls Razor Ltd. and the essence of the bargain was that the sum advanced should not become part of the assets of Rolls Razor Ltd. but should be used exclusively for payment of a particular class of its creditors, namely, those entitled to the dividend. This entailed the necessary consequence that if, for any reason, the dividend could not be paid, the money was to be returned to Quistclose. The word "only" was not capable of bearing any other effect. $^{4}$

His Lordship was emphatic in his disavowal of the idea that a transaction giving rise to a legal action for debt could not also create a trust. He said:

"There is surely no difficulty in recognising the co-existence in one transaction of legal and equitable rights and remedies; when the money is advanced, the lender acquires an equitable right to see that it is applied for the primary designated purpose . . . : when the purpose has been carried out (i.e. the debt paid) the lender has his remedy against the borrower in debt; if the primary purpose cannot be carried out, the question arises if a secondary purpose (i.e. repayment to the lender) has been agreed, expressly or by implication: if it has, the remedies of equity may be invoked to give effect to it, if it has not (and the money) is intended to fall within the general fund of the debtor's assets) then there is the appropriate remedy for recovery of a loan. I can appreciate no reason why the flexible interplay of law and equity cannot let in these practical arrangements, and other variations if desired; it would be to the discredit of both systems if they could not."'s

\section{The early authorities}

In upholding the claim put forward by Quistclose, the House of Lords followed a long line of cases dating back to the beginning of the last century. According to Lord Wilberforce the fact that arrangements of this character for the payment of a person's creditors by a third person, give rise to a relationship of trust, in favour, as a primary trust, of the creditors, and secondarily, if the primary trust fails, of the third person, has been recognised in a series of cases over some 
150 years. Toovey v. Milne marks the fons et origo of this stream of authority. ${ }^{6}$ Abbott C.J. said:

"I thought at the trial, and still think, that the fair inference from the facts proved was that this money was advanced for a specific purpose, and that being so clothed with a specific trust, no property in it passed to the assignee of the bankrupt. Then the purpose having failed, there is an implied stipulation that the money shall be repaid."?

In Toovey v. Milne A advanced money to his brother-in-law, B, for the purpose of B settling with his creditors. ${ }^{8}$ That purpose failed and B was declared bankrupt. What was left of the money was repaid to A by the bankrupt. The court held that this repayment was protected and that the assignees in bankruptcy could not recover the money so repaid.

The principle enunciated in Toovey v. Milne was applied sub silentio as it were in Gibert v. Gonard since the case is nowhere cited. ${ }^{9}$ Gibert v. Gonard is a case where A lent money to B for the purchase of a particular business. B in fact paid the money into his general bank account and drew against it to the extent of several hundred pounds for the purpose of meeting certain of his own personal liabilities unconnected with the business to be purchased. $B$ became bankrupt before the property acquisition could be completed and it was held that $A$ was entitled to follow and recover the money in the bank account in the same manner as if it had been in terms a trust fund. According to North J. it was very well known law that if one person makes a payment to another for a certain purpose, and that person takes the money knowing that it is for that purpose, he must apply it to the purpose for which it was given. He may decline to take it if he likes but if he chooses to accept the money tendered for a particular purpose there was a legal obligation to apply it for that purpose. ${ }^{10}$ In other words a duty was cast upon the borrower which placed him in the position of a trustee of the money advanced.

Re Rogers is another authority, this time of the Court of Appeal, to the same effect. "This is a case where A, a money-lender, lent money to B to enable pressing creditors to be paid. Some of that money was applied by $B$ towards meeting the claim of $\mathrm{C}$, a judgment creditor. $\mathrm{B}$ was adjudicated bankrupt and the question arose whether the trustee-in-bankruptcy could sue $C$ to recover the money. The Court of Appeal declined to answer in the affirmative. The holding was that since the advance to $B$

6. (1819) 2 B. \& Ald. 683. See also Edwards v. Glynn (1859) 2 E. \& E. 29; Gibert v. Gonard (1885) 54 L.J. Ch. 439; Re Rogers (1891) 8 Morr. 243; Re Drucker [1920] 2. K.B. 237; Re Watson (1912) 107 L.T. 783; and Re Hooley [1915] 84 L.J.K.B. 181. See also the line of cases mentioned by Goode infra. n.59 at pp. 180-181 including Re Pallitt [1893] 1 Q.B. 455; Re Mid-Kent Fruit Factory [1896]

1 Ch. 567; Re City Equitable Fire Insurance Co. Ltd (No. 2) [1930] Ch. 293.

7. Ibid. at p. 684 .

8. Ibid. The early cases are well analysed by Millett, (1985) 101 L.Q.R. 269 at 270-274.

9. Supra. n.6

10. lbid. at 440 .

11. 'Supra. n.6.' Millett supra. n.8, at 273 describes it as the decision of a strong Court of Appeal. The court consisted of Lindley, Bowen and Kay L.JJ. 
was for the special purpose of enabling his creditors to be paid, it was impressed with a trust for that purpose and never became the property of B. Lindley L.J. observed:

"I entertain no doubt that $[A]$ could have obtained an injunction to restrain the bankrupt from using that money for any purpose except that of paying his pressing creditors. If this be so, the money never was the bankrupt's in any proper sense so as to vest in his trustee as part of his general assets." 12

Kay L.J. stated:

"The desire and intent of $[A] \ldots$ was to prevent the bankruptcy of $[B] \ldots$ The true result of the evidence seems to me to be that the advance by [A] was for this special purpose, and the money was impressed with a trust, so that [A] could have prevented its being otherwise used." 13

As one commentator has pointed out one striking characteristic of these 19th. century cases is the immediacy of the debtor's need for outside sources of funding. ${ }^{14}$. The party advancing the money is doing so on an emergency or rescue basis while the debtor serves merely as a conduit pipe through whom the money is channelled to the outside creditor. It can fairly be said that the debtor's possession of the money does not mislead. Nobody is induced into further dealings with him on the basis of a false assumption as to creditworthiness. Any benefit that might accrue to general creditors if the conduit pipe broke down would be pure windfall. Moreover the payer is not receiving any special premium consequent on the transaction being characterised as a mere loan. Thus it does not seem unfair to general creditors if the payer is allowed to return or recover the money as the case may be.

\section{Doctrinal criticisms of Quistclose}

The notion of the Quistclose trust has engendered some discussion and disquiet insofar as the finer points of the law of trusts are concerned. ${ }^{15}$ Issues for debate include whether the trust is properly constituted, questions of enforcement, revocability and the identity of the beneficiary. Consideration of these questions will be postponed until later in the article but one might legitimately inquire here about why the primary purpose was deemed to have failed in Quistclose. Some observers have no doubts. For instance in Re Northern Developments (Holdings) Ltd. Sir Robert Megarry V.C. said:

" [I $] \mathrm{n}$ the Quistclose case, the primary purpose was clear, simple and definite, both in its ambit and frustration. The purpose was to pay a particular debt due to particular creditors upon a particular date; and once the company [B] had

12. Ibid. at 248 .

13. Ibid. at 249.

14. See Bridge supra. n.1.

15. See in particular Millett 'supra. n.8', and Rickett supra. n.1.2 
decided to go into liquidation, that primary purpose plainly could never be accomplished. Once the voluntary winding up had commenced, the dividend could not be paid in competition with other creditors ... and so in the circumstances no trust for the payment of the dividend could be carried out." 16

There are some difficulties with this analysis however. ${ }^{17}$ For a start the dividends had actually been declared before the loan was obtained. Case-law establishes that the declaration of a dividend by resolution of the shareholders brings into being an immediate debt in their favour unless a later date for payment has been expressly specified. The argument therefore is that the trust to pay the dividends was complete. Subsequent liquidation of the company could not unravel that trust. ${ }^{18}$ In his exploitation Megarry V.C. relied on what is now section 74(2)(f) of the Insolvency Act 1986 which relegates shareholder claims for unpaid dividends behind debts due to external creditors. Clearly the statutory provision precludes debts based upon unpaid dividends being proved in competition with the claims of outside creditors. The legislative statement would not seem though to catch trusts of dividends. ${ }^{19}$ As one judge writing extra-curially put the matter: "It does not prevent a trustee from paying trust money, which ex hypothesis does not belong to the company, to the persons beneficially entitled thereto. " 20

The better view may be that the underlying purpose behind the conditional loan arrangements in Quistclose was not merely the payment of a dividend to shareholders but also the preservation of the company as a going concern. ${ }^{21}$ In other words, the case is explicable with reference to a corporate salvage rationale. ${ }^{22} \mathrm{~A}$ similar explanation may be proferred in respect of Re E.V.T.R. Ltd. ${ }^{23}$ This is a case where the appellant, $\mathbf{B}$, had the good fortune to win a big prize on the premium bonds. He was not in the business of lending money but was persuaded to lend $£ 60,000$ to a company, EVTR Ltd., that was experiencing financial difficulties. The company was run by a friend of his. B was advised by his accountant, in no uncertain terms, that he would be wasting his money if he simply lent it unconditionally to the company. What happened therefore, was that B advanced to solicitors acting for EVTR Ltd.,

16. Unreported, October 6, 1978. Despite its unreported status the case has been referred to extensively by academic commentators and was also the subject of lengthy discussion in Carreras Rothmans Ld $\mathrm{v}$. Freeman Mathews Lid. [1985] Ch. 207.

17. See generally H.A.J. Ford and W.A. Lee, Principles of the Law of Trusts (1990) at p.31; Millett 'supra. n.8', at 275-276; Rickett supra. n.1.2; Oditah (1992) 108 L.Q.R. 459 at 475.

18. Millett $i b i d$. at p. 276 argues that there is not good reason why the rights of the shareholders to the money should be affected by the subsequent liquidation of the company, B. The desire of B's liquidator to repay the loan to A rather than to pay the dividend is understandable though as the effect of paying the dividend would be to substitute $\mathrm{A}$, an ordinary creditor, for $\mathrm{C}$, a deferred creditor, to the detriment of the general body of creditors.

19. See Oditah, supra. n. 17 at 475.

20. See Millett, supra. n.8, 269 at 276.

21. It might also be the case that there was a further condition attached to the payment to the effect that the money should be utilised for paying dividends only if Rolls Razor obtained further finance by a named date. On this point see [1968] Ch. 504 at 549-551.

22. See R.P. Austin, (1986) 6 O.J.L.S. 444 at 455.

23. [1987] B.C.L.C. 646. 
the sum of $£ 60,000$ " for the sole purpose of buying new equipment". Unfortunately, EVTR Ltd. did not have the balance necessary to buy the equipment outright and so a more complicated scheme was embarked upon with two other companies. The first company was the manufacturer of the equipment. EVTR Ltd. contracted with this company for the supply of new equipment to be delivered within 7 months and in the meantime to supply the company with temporary equipment. EVTR Ltd. also entered into a contract with another company under which the second company agreed to take over EVTR Ltd.'s obligations under the contract with the manufacturer by buying the new equipment and then leasing it to EVTR Ltd. The contract involved EVTR Ltd. paying a deposit of $£ 60,000$ plus 36 monthly instalments.

The bank who had financed EVTR Ltd. appointed receivers to the company before the new equipment arrived and the two supplier companies returned the $£ 60,000$ less various agreed deductions. The question arose whether the refunded sum formed part of the general assets of EVTR Ltd. available for distribution to its secured creditors or whether it was impressed with a trust in favour of B. This involved consideration of the point whether the original purpose of the transaction had been accomplished. In other words, had B been disappointed in his aim of making himself an unsecured creditor of EVTR Ltd? ${ }^{24}$ The Court of Appeal answered in the affirmative. Dillon L.J. suggested that the purpose of B from which any trust was to be implied was, realistically, the purpose of EVTR Ltd, acquiring new equipment and not the purpose of EVTR Ltd entering into an abortive contract for the lease/purchase of new equipment. Bingham L.J. opined that it would strike most people as very hard if $B$ were in this situation to be confined to a claim as an unsecured creditor of the company. ${ }^{25}$ Moreoever, it must be pointed out that B was not a trade creditor conversant with credit risk and the bank's debenture had been granted some time before the injection of credit by $\mathrm{B}$. As one commentator perceptively observes: "The bank would have been a windfall creditor if the Quistclose trust, and its failure of achievement, had not been recognised." 26

\section{Application of the conditional payment principle - some controversial cases}

If the primary purpose of the payment had been carried out in Quistclose then the result achieved is one of credit substitution. ${ }^{27} \mathrm{~A}$, the payer, becomes a creditor of $\mathrm{B}$, the person to whom payment is made, instead of $\mathrm{C}$, the third party creditors who are the ultimate intended recipients of the payment. Before the payment was made, there was no pre-existing relationship of debt between $\mathrm{A}$ and $\mathrm{B}$.

24. To borrow the felicitous expression of Michael Bridge supra. n.1 at 354 .'

25. Supra. n. 23 at 652 . The judge added that while it was literally true that the fund which the appellant, B, provided was applied to the stipulated purpose, the object of the payment was not achieved and that was why the balance was repaid.

26. See Bridge supra. n.1 at 356.

27. See Priestley, supra. n.1 at p. 230 who points out that the attitude of other sources of finance might change if the credit substitution were known, but this is unlikely in the case of unsecured credit. 
Carreras Rothmans Ltd. v. Freeman Mathews Treasure Ltd. involves an extension of the Quistclose principle in that A stood in a relationship of debt to B prior to the time of making the payment. ${ }^{28}$ The plaintiff tobacco manufacturer arranged that the defendant advertising agency would place advertisements for it in newspapers, periodicals and by means of posters. The services of an agency were availed of for this purpose so as to secure deductions on advertisement fees. The advertising agency as principal thereby incurred debts to various media creditors. These debts it recharged to the plaintiff along with its own fees. The plaintiff became concerned about the solvency of the advertising agency. If the agency went into liquidation leaving media creditors unpaid the plaintiff's reputation would suffer. Alternatively, it would have to pay off the media creditors to avoid disruption of a major advertising campaign that it had launched. Therefore with the agreement of the defendant, the plaintiff paid into a special account a sum equivalent to the money due to the third party creditors. The advertisng agency went into insolvent liquidation but before the media creditors could be paid the liquidator froze the special account. The plaintiff, as had been feared, was forced to discharge the sums due to the media people so as to maintain its advertising initiative. In return it took an assignment of the debts due to the creditors. Thereupon it sought to recoup the moneys in the special account: a claim resisted by the defendant and its liquidator.

Peter Gibson J. acknowledged the factual differences between Quistclose and the present case. ${ }^{29}$ In Quistclose the transaction was one of loan with no contractual obligation on the part of the lender to make payment prior to the agreement for the loan. In the present case there was no loan but there was an antecedent debt owed by the plaintiff. He held, however, that this factual difference was not legally material. The principle in all these cases is that equity fastens on the conscience of the person who receives from another property transferred for a specific purpose only and not therefore for the recipient's own purposes, so that such person would not be permitted to treat the property as his own or to use it for other than the stated purpose. ${ }^{30}$

Carreras Rothmans has attracted some criticism on the score that it ignores the possible application of the preference provision in the insolvency legislation. ${ }^{31}$ Basically the legislation invalidates acts done by a company within 6 months prior to the commencement of winding up which have the effect of giving a creditor a preference over other creditors and which were influenced by a desire to achieve that result. ${ }^{32}$. The relevant period is two years if the act is done in favour of a person connected with the company otherwise than by reason of his being its employee. ${ }^{33}$

28. [1985] Ch. 207.

29. Ibid. at 222 .

30. Ibid.

31. See Priestley, supra. n.1 at 235-236.

32. Sections 238-24l of the Insolvency Act 1986. The relevant period is two years in the case of a payment made in favour of a person connected with the company otherwise than by reason only of being its employee. For the definition of connected person see s. 249 of the Act. Prior to the Insolvency Act reforms, the law concerned itself only with fraudulent preferences as defined in $\$ .615$ of the Companies Act 1985 re-enacting earlier legislation.

33. For the definition of connected person see s. 249 of the 1986 Act. 
The material provisions are contained in section 238-241 of the Insolvency Act which revamp the old law as embodied in section 615 of the Companies Act 1985 and preceding legislation. The previous statutory dispensation nullified fraudulent preferences and these were judicially held to cover only acts done with the dominant intention to prefer ${ }^{34}$ A payment made under pressure, however, escaped invalidation as a fraudulent preference as the element of pressure was said to remove the dominant intention to prefer. ${ }^{35}$ Thus the greater the pressure exerted by the debtor the greater the likelihood that any payment to him would not be stigmatised as a fraudulent preference. ${ }^{36}$

The relevance of cases on the old law in the new statutory context was however denied by Millett J. in Re MC Bacon Ltd. The new law strikes down acts that were influenced by a desire to put a creditor in a superior position vis-à-vis other creditors. The judge distinguished between desire and intention. Intention was objective while desire was subjective. A person might have to choose between the lesser of two evils without desisting either. A payment could only be attacked if there was a positive wish to improve the creditor's position. Once the requisite desire was present however the payment would be condemned. The desire need not be the causative or decisive factor in the transaction. Something of a discordant note was struck by Robert Wright Q.C. in Re Beacon Leisure Ltd. ${ }^{38} \mathrm{He}$ said that in many cases the difference between the objective test of intention and the subjective test of desire might be small.

How does this exegesis apply in the present context? The argument goes something like this. Carreras Rothmans stands as authority for the proposition that the debtor of a company may discharge the debt by paying it to the company on terms which require the company to lay it aside and hold it on trust for payment only to creditors of the company who have been nominated by the debtor. The argument proceeds along the lines that the creditor negotiates away the right to receive the money beneficially in exchange for an arrangement under which one class of its unsecured creditors are satisfied from the sum paid. The consensual element in the payment is said to transform it into an act done by the recipient of the payment and so attracting the invalidating effect of the preference provisions..$^{39}$ This conclusion is by no means

34. The judgment of Lord Tomlin in Peat v. Gresham Trust Ltd. [1934] A.C. 252 is to this effect and his observations have been amplified in numerous other judicial decisions.

35. See for instance Re Eric Holmes Ldd. [1965] Ch. 1052. So if a creditor is paid off in response to a threat of legal action the intention of the company paying the debt is construed as being that of removing the threat rather than preferring the creditor.

36. Opinions differ about whether this state of affairs has survived the new statutory regime. It may be argued however that giving a preference to a person cannot be said to have been influenced by a desire to put the person in a preferential position if the preference would inevitably have been given whether or not the desire was present - in other words if there was an overwhelming reason for giving the preference rendering all other considerations superfluous. A majority of the Cork Committee favoured the retention of the old rule. Their contention was that a creditor who has taken active steps to obtain payment of his own debt should in principle be allowed to retain the fruits of his diligence (Cmnd. 8558 (1982) at para. 1256). 37. [1990] B.C.L.C. 324.

38. [1991]B.C.C. 213.

39. It should be noted that Priestley's argument (supra n.1) is made in the context of $s .122$ of the Australian Bankruptcy Act which is worded differently than its U.K. counterpart. 
inevitable. If the payment is made only on condition that it is applied for a specific purpose the recipient can hardly be said to have bargained away the right to receive the payment without strings attached. Moreover, the "influenced by a desire to" criterion may not be satisfied. ${ }^{40}$

There is another layer of complexity. If the primary purpose of the payment was carried through in Quistclose one category of unsecured debt is substituted for another. One unsecured creditor is paid off and another takes its place. Now to the what if. Say a loan secured by a charge over the company's assets is made on condition that the amount of the loan is used to discharge earlier unsecured indebtedness. How does this affect the picture? Generally floating charges granted by an insolvent company within the 12 month period prior to its liquidation are invalid except to the extent of any fresh advance. ${ }^{41}$ Does the conditional loan count as a fresh advance? ${ }^{42}$ The answer seems to be no at least as a general proposition, though there is some discordance in the authorities. ${ }^{43}$. The incongruity dates from Re Matthew Ellis \& Co Ltd. ${ }^{44}$ In this case the Court of Appeal rejected the view advanced by Astbury J. in Re Hayman, Christy \& Lilly Ltd. which exempted from the fresh advance exception cash payments made conditionally as to their mode of application..$^{45}$

Romer L.J. said:

"Where a man advances money to a company on the security of a debenture on the terms that the money so advanced is to be applied by the company in discharge of one of its existing liabilities or in the acquisition of some asset which the company does not at the moment possess, the money paid by the lender did not cease to be cash paid to the company merely by reason of the imposition of that condition." ${ }_{46}$

The other members of the court, Lord Hanworth M.R. and Slesser L.J. were equally adamant about imposing the limitation that the fresh advance must not be applied in satisfaction of an antecedent debt. Something of a via media was suggested, however,

40. It could be said that the payment has been made as a result of pressure which negates any desire to prefer. 41. The relevant provision in section 245 of the Insolvency Act 1986 . According to this provision a floating charge on the company's undertaking or property created at a relevant time is invalid except to the extent of the aggregate of - (a) the value of so much of the consideration for the creation of the charge as consists of money paid, or goods or services supplied, to the company at the same time, or after, the creation of the charge, (b) the value of so much of that consideration as consists of the discharge or reduction, at the same time as, or after, the creation of the charge, of any debt of the company, and (c) the amount of such interest (if any) as is payable on the amount falling within paras. (a) or (b) in pursuance of any agreement under which the money was so paid, the goods or services were so supplied or the debt was discharged or reduced.

42. See generally Rajak, Company Liquidations (1981) at pp. 286-287.

43. At least Kenny J. seemed to think so in the Irish case Re Daniel Murphy Ltd. [1964] I.R. 1 at 15.

44. [1933] Ch. 458.

45. [1917] 1 Ch. 283, at 285.

46. [1933] Ch. 458 at 477. 
by Lord Hanworth M.R. He said that the court had to have regard to transactions which might often be complicated and difficult. The task was to determine whether in substance the debenture sought to be invalidated had been issued for cash paid to the company. ${ }^{47}$ If it had been, then, although the money might have been used by the company for the purpose of meeting a liability already incurred, the security stood good.

The facts of Re Matthew Ellis \& Co Ltd., do not indicate villainy and perhaps show why the section was given the interpretation that it was. The case concerned an insolvent company that was granted a loan by its chairman. The latter was also a partner in a firm which supplied the bulk of its stock of goods to the company. The chairman considered that an advance might save the company. Before advancing the money he was informed by his partners that they would only consent to continue to supply the company with goods on credit if the past debt to the firm was paid. The advance was made secured by a floating charge over the company's assets and out of this money a substantial sum was applied in discharging the past debt to the firm. It was held that the floating charge was good in respect of the entire sum advanced.

A more absolutionist line on the section was taken by the Northern Ireland Court of Appeal in Revere Trust Ltd. v. Wellington Handkerchief Works Ltd. ${ }^{48}$. Here the Court expressed approval for the dictum that cash payments, to count as fresh advances, must be absolute and uncontrolled.49. Andrews L.J. drew a clear distinction between a cash payment to the company and the payment of an existing liability of the company. The latter was not a cash payment to the company to do what it liked with as its own moneys. ${ }^{50}$ While Revere Trust Ltd. v. Wellington Handkerchief Works Ltd., predates Re Matthew Ellis \& Co Ltd. in point of time, it is nowhere referred to in the latter case.

Re Matthew Ellis \& Co Ltd. was considered but ultimately distinguished by Simonds $\mathrm{J}$. in Re Destone Fabrics Ltd. ${ }^{51}$ The judge suggested that the test in such cases may well be whether the transaction is to be regarded as one intended bona fide for the benefit of the company, or whether it is intended merely to provide certain moneys for the benefit of certain creditors of the company to the prejudice of other creditors of the company. ${ }^{52}$

This test was applied by Nourse $\mathbf{J}$. in Re GT Whyte \& Co Ltd. ${ }^{53}$ This is a case where a fresh secured loan was made by a wholly owned subsidiary of a secured creditor. The judge held that as a matter of substance the new advance was intended to secure the past indebtedness to the unsecured creditor and so the security was invalidated. So we are left with a "substance of the transaction" test. Was the intention

47. Ibid. at 474 .

48. [1931] N.I. 155.

49. Thus applying the dictum of Astbury J. in Re Hayman, Christy \& Lilly Lid. supra. n.45.

50. Supra. n. 48 at 155 .

51. [1951] Ch. 319.

52. Ibid. at 324-325.

53. [1983] B.C.L.C. 311. See also Re Fairway Magazines Ltd. [1993] B.C.L.C. 643. 
to provide a genuine commercial benefit for the company or merely to substitute secured for unsecured indebtedness?

It should be noted that all these cases were decided under old legislation which invalidated floating charges created within a certain period prior to the commencement of winding up, except to the extent of "cash paid" to the company at the time of the creation of the charge, and in consideration for the charge. The wording has since been revised. The exception in s.245(2)(a) and (b) of Insolvency Act 1986 now covers the aggregate of:

" (a) the value of so much of the consideration for the creation of the charge as consists of money paid, or goods or services supplied, to the company at the same time as, or after, the creation of the charge,

(b) the value of so much of that consideration as consists of the discharge or reduction, at the same time as, or after, the creation of the charge, of any debt of the company ..."

It is submitted that the new wording and in particular, the introduction of paragraph (b) would make no difference to the result in the cases discussed. The contention is that the old debts are not in fact discharged as a matter of substance. ${ }^{54}$

Failure to take account of the invalidating provisions of insolvency legislation is also a criticism levelled at Re Kayford Ltd. ${ }^{55}$ This case concerned a company which carried on a mail order business. The company was in financial difficulties and took advice on how best to protect customers. The customers were sending money to the company in anticipation of being supplied with goods. The company was advised by accountants to open a Customers Trust Deposit Account into which all further sums of money sent by customers for goods not yet delivered should be paid, so that should the company be forced into liquidation, these sums could be refunded to the customers who had sent them. The company largely accepted that advice but instead of opening a new account used a dormant deposit account in the company's name.

Megarry J. held that a trust in favour of the customers had been created. The whole object of what was done was to ensure that the moneys remained in the beneficial ownership of those who sent them, and a trust was the obvious means of achieving

54. See Gower's Principles of Modern Company Law (5th. ed., 1992) at p.424 but compare R.E. Pennington, Corporate Insolvency Law (1991) at pp.221-222.

55. Supra. n.2. It has been argued that Re Kayford Ltd. and its direct derivatives are not examples of Quistclose type trusts. The contention is that in these cases recovery by the original "lenders" is by virtue of an express trust rather than a resulting trust. For a development of this argument see Rickett supra. $\mathrm{n} .1$ at 609 . In this article a broader commercial approach to conditional payments is taken and there is no doubt that $R e$ Kayford $L t d$. at least in the way that the judge saw the facts, involves an example of a conditional payment. 
this. ${ }^{56}$ The sender could create a trust by using appropriate words when he sends the money or the company could do it by taking suitable steps on or before receiving the money. If either was done the obligations in respect of the money were transformed from contract to property, from debt to trust.

The judgment of Megarry J. is characterised by a concern for members of the consuming public some of whom, in his words, "can ill afford to exchange their money for a claim to a dividend in the liquidation, and all of whom are likely to be anxious to avoid this. "'57 Some might think that this concern is misguided. For instance the Cork Committee on Insolvency Law and Practice suggested that the customer who paid in advance for goods or services to be supplied later extends credit just as surely as the trader who supplies in advance goods or services to be paid for later. ${ }^{58}$ There was no essential difference. Each gave credit; and if the credit was misplaced each should bear the loss rateably. On the other hand, prepayment customers may not perceive themselves as providers of unsecured credit. There is much to be said for the view of the Office of Fair Trading that prepayment customers do not consciously become creditors, and that they have no means of securing the money which they advance.

In Re Kayford Ltd. Megarry J. said that no question of a fraudulent preference arose. One was concerned here not with the question of preferring creditors, but of preventing those who pay money from becoming creditors, by making them beneficiaries under a trust. ${ }^{59}$

This analysis has not been universally accepted. Attention may have been diverted from the question of who owned the moneys at the time that the company declared itself trustee of them. If the company owned the moneys at that time, then the declaration of trust had the effect of impermissibly altering the statutory order of priorities for payment of creditors. ${ }^{60}$

56. Ibid. at 282 . He said that payment into a separate bank account was a useful (though by no means conclusive indication of an intention to create a trust, but there was nothing to prevent the company from binding itself by a trust even if these were no effective banking arrangements.

57. Ibid. at 282. The judge added: "In cases concerning the public, it seems to me that where money in advance is paid to a company in return for the future supply of goods or services, it is an entirely proper and honourable thing for a company to do what this company did, on skilled advice, namely, to start to pay the money into a trust account as soon as there begin to be doubts as to the company's ability to fulfil its obligations to deliver the goods or provide the services. I wish that, sitting in this court, I had heard of this occurring more frequently; and I can only hope that I shall hear more of it in the future." 58. Cmnd. $8558(1982)$ at para. 1052.

59. Supra. n.2 at 281. See also Goode, Payment Obligations in Commercial and Financial Transactions (1983) p.18 n.64.

60. See Waters, (1983) 21 Alberta Law Review 395 at 417 . On the other hand it has been argued that if money is received in circumstances in which the court would hold the recipient accountable as a constructive trustee, then there will be no preference because the creation of the fund will not have put the customer in a better position than that customer would have enjoyed in an ensuing bankruptcy or liquidation. In other words there is no factual preference regardless of whether there was the requisite desire to produce that effect. For this argument see Hamish Anderson, "The Treatment of Trust Assets in English Insolvency Law" in Ewan McKendrick ed., Commercial Aspects of Trusts and Fiduciary Obligations (1992). The argument is developed infra in connection with the discussion of Re Chelsea Cloisters Ltd. (1981) 41 P. \& C.R. 98. 
Despite all the criticisms Re Kayford Ltd., was followed by the Court of Appeal in Re Chelsea Cloisters Ltd. ${ }^{61}$ This was a case where the company which was the underlessee of a block of flats granted numerous tenancies. It took a deposit from individual tenants in respect of any sum which might be due from the tenant at the end of the tenancy for damage, breakages and compensation. Initially there were no special arrangements for dealing with the deposits of the tenants but when the company got into financial difficulties a chartered accountant was appointed to supervise the running of the company. This supervisor expressed a wish that the tenants' deposits should be kept separate from other moneys of the company and so they were segregated from the company's general assets and paid into a Tenants' Deposit Account. The company went into liquidation and it was held that the deposits were held on trust for the tenants.

Lord Denning said that the deposits were not impressed with a trust from the very beginning. ${ }^{62}$ The creation of the special arrangements, however, established a trust. ${ }^{63}$ No issue of improper preference was raised. ${ }^{64}$ According to Lord Denning the supervisor realised that the company was in a hopeless position; it had no money to pay anybody and there was a danger that these deposits might fall into the hands of the other creditors of the company, contrary to the justice of the case. ${ }^{65}$ It must be pointed out, however, that the supervisor nowhere used explicit trust language; terminology that ought to have been familiar to a chartered accountant. The decision has been viewed as an exercise in discretionary justice. The company had gone into liquidation with total debts approximating to $£ 50$ million whereas the sum of the tenants' deposits was in the region of $£ 20,000$. Greater joy would be experienced by meeting the claims of the tenants in full rather than by spreading the piteously small sum of money almost invisibly across the general range of creditors. ${ }^{66}$

It has been suggested that for the company to claim beneficial ownership of the deposit money would involve more than a taint of fraudulent trading. Under the legislation in force at the time Re Chelsea Cloisters Ltd., was decided, where a company had gone into liquidation the court could direct particular payments to particular creditors who had been defrauded. ${ }^{67}$ In 1986 a wider notion of wrongful trading was

61. (1981) 41 p. \& C.R. 98. The case was approved in Re Lewis's of Leicester Lid. [1995] BCC 514. 62. Ibid. at 101 . He referred to Potters v. Loppert [1973] Ch. 399. See also Bridge L.J. at 102 and Oliver L.J at 104 who were disinclined to express an opinion on this point.

63. Referring to Henry v. Hammond [1913] 2 K.B. 5151 and Hughes v. Stubbs (1842) 1 Hare as well as Re Kayford Lid. supra. n.2.

64. Hamish Anderson, supra. n.60 at p. 178 point out that the person responsible had acted in the belief that there was an obligation to protect the deposits thereby negativing the possibility of there being an improper preference. In Re Vautin [1900] 2 QB 325 it was held with reference to the old statutory dispensation that a payment made under an honest and reasonable belief that there was a legally binding obligation to pay could not be struck down as an improper preference. See also on this point Re Lewis's of Leicester Ld. [1995] BCC 514.

65. Supra. n.61 at 102.

66. See Bridge, supra. n. 1 at 357.

67. Section 332 of the Companies Act 1948 as interpreted by a majority (Lord Denning M.R. and Danckwerts L.J.) of the Court of Appeal in Re Cyona Distributors Lid. [1967] Ch. 889. 
introduced in the insolvency legislation ${ }^{68}$ but the concept of fraudulent trading was retained to cover specific cases. ${ }^{69}$ In situations of both frauduent and wrongful trading, however, payments ordered to be made only go to swell the general assets of the company. Such payments cannot be earmarked by the court for specific creditors who may have been defrauded.

\section{Application of the conditional payment principle - some uncontroversial cases}

Re Kayford Ltd. and Re Chelsea Cloisters Ltd. may be distinguished from Re Nanwa Gold Mines Ltd. which seems safe from criticism. ${ }^{70}$ In Re Nanwa Gold Mines Ltd. money was advanced on the faith of a promise to keep it in a separate account, and Harman J. held that a trust had been created. He contrasted Moseley v. Cressey's Co. where a simple statement that application moneys would be refunded was held not to bind moneys standing in a bank to the credit of the company, with a trust in favour of the depositors. The intent of the promise to keep in a separate account meant that the moneys would not be mixed with the company's moneys. ${ }^{72}$.

Many of the great cases in the company law field involve speculative projects in far flung corners of the globe during the halcyon days of imperial expansion. ${ }^{73}$ Such projects often involved great risk, and to minimise the risk factor the trust arrangement was often employed. Financiers instead of advancing money directly to the company would advance it to intermediaries, trustees, who would release it to the company at various stages of the project. National Bolivian Navigation Co. v. Wilson involved such a project and arrangement. ${ }^{74}$ This is a case where money had been subscribed by investors for a particular purpose namely the construction of a railway linking Brazil and Bolivia. The money was placed in the hands of trustees for the investors, and it was the duty of the trustees to pay portions of the money over to the company

68. Section 214 of the Insolvency Act 1986. Under this provision once a director, or shadow director, knows, or ought to have concluded, that there was no reasonable prospect that a company would avoid going into insolvent liquidation, he must take every step with a view to minimising potential loss to company creditors. Otherwise the person may be declared liable to make such contribution (if any) to the company's assets as the court thinks proper.

69. Ibid. section 213 . This section applies to any liquidation whereas s. 214 is confirmed to cases of insolvent liquidation. Moreover, 213 covers any person who was knowingly party to the carrying on of the business in a fraudulent manner whereas $\mathbf{s . 2 1 4}$ is limited to directors and shadow directors.

70. [1955] 3 All E.R. 219. See also National Bolivian Navigation Co. v. Wilson (1880) 5 App. Cas. 176. Elkins v. Capital Guarantee Society (1900) 16 T.L.R. 423; Re Independent Air Travel Ltd. [1961] 1 Lloyd's Rep. 604 and Smith v. Liquidator of James Birrell Lid. 1968 S.L.T. 174

7I. (I865) L.R. I Eq. 405.

72. Supra. n.70 at 223.

73. One might instance in this connection some of the cases on promoters like Erlanger v. New Sombrero Phosphate Co. (1878) 3 App. Cas. 1218.

74. Supra. n.70. 
as portions of the intended railroad were constructed. The House of Lords held that if no such railroad nor any portion of it was constructed, and its construction became impracticable, the bondholders were entitled to demand from the trustees repayment of what remained in their hands. ${ }^{75}$.

Another area where the Quistclose principle has been uncontroversially applied lies in relation to employee claims for moneys in the hands of insolvent employers. A case in point is Re Independent Air Travel Ltd. ${ }^{76}$ This is a case where a company insured the lives of its employees, three of whom later died in an air crash. It was a condition of employment that the company should insure the lives of the deceased employees for the latter's benefit. The insurers in fact paid over on foot of the insurance policies' moneys for distribution to the families of the deceased but the company went into receivership before this task could be done. Plowman J. held that the moneys had been received on trust for the estate of the three deceased, although no express words of trust had been employed.

A similar result was reached in the Scottish case, Smith v. Liquidator of James Birrell Ltd. ${ }^{77}$ This is a case where a company had paid into a special bank account moneys received from an insurance comany representing different employee pension and insurance schemes which the company had decided to discontinue. The sum received was for the benefit of the employees in the employment of the company at the date of the discontinuance of the scheme. Lord Fraser, in the Outer House of the Court of Session, decided that this money did not form part of the general assets of the company. The money was clearly distinguishable and capable of being disentangled from the company's own funds, and it ought to be paid to the former employees of the company entitled thereto. ${ }^{78}$

\section{Formalities for the establishment of trust}

There remains to be considered the prerequisites for the creation of a valid express trust, namely the three certainties - certainty of intention, certainty of subject-matter and certainty of objects. Moreover, if the declaration of trust relates to land, signed written evidence must be available before the trust can be enforced. ${ }^{79}$.

\section{Certainty of intention}

This issue was discussed in Re Kayford Ltd. where Megarry J. said that a trust can be created without using the words "trust" or "confidence" or the like. The

75. According to Lord Blackburn the trust was created by the prospectus on the faith of which the bondholders, or those whom they represent, lent their money: ibid. at 207.

76. Supra. n.70.

77. Supra. n. 70 .

78. Ibid. at 175 .

79. Section 53(1)(b) of the Law of Property Act 1925. 
pertinent question was whether a sufficient intention to create a trust had been manifested. ${ }^{80}$ Sufficiency of intention to create a trust was not manifested in Swiss Bank Corporation v. Lloyds Bank Ltd. ${ }^{81}$

The facts of the case are complicated, but the nub of the issue was whether a lender of money, the Swiss Bank Corporation, had obtained any kind of proprietary interest in securities which the borrower, as the lender knew, wished to use the loan to invest in.

The loan agreement did not actually cover such a proprietary interest, but in it, the borrower did promise that it would observe all the conditions attached by the Bank of England to its consent for the loan. These conditions included the requirements that the loan was to be used exclusively for the purchase of certain foreign securities (F.I.B.I. securities) and that the interest on, and capital of the loan were to be repaid to the Swiss Bank Corporation out of the F.I.B.I. securities or the proceeds of their sale. The borrower subsequently charged the F.I.B.I. securities to Lloyds Bank as security for a guarantee given in respect of a further loan from that bank. When the Swiss Bank Corporation sought repayment of the loan, it claimed to have a better interest in the securities than Lloyds Bank. Although the Judge at first instance, BrowneWilkinson J., held in the plaintiff's favour, both the Court of Appeal and the House of Lords held against the Swiss Bank Corporation.

None of the appellate judges in the Swiss Bank case could see anything in the loan which specifically said that the borrowers would repay the loan out of the F.I.B.I. securities, nor would they imply any such promise. Both the Court of Appeal and the House of Lords' judges were content to apply the law stated by Lord Wrenbury in Palmer v. Carey:

"An agreement for valuable consideration that a fund shall be applied in a particular way may found an injunction to restrain its application in another way. But if there be nothing more, such a stipulation will not amount to an equitable assignment. It is necessary to find further, that an obligation has been imposed in favour of the creditor to pay the debt out of the fund." 82

The requisite certainty of intention to create a trust was also held not to have been established in Re Multi Guarantee Co Ltd. ${ }^{83}$ This is a case where a company, M.G., was incorporated to market warranties for domestic appliances, which provided insurance after the manufacturer's guarantee expired. $V$ was the owner of a chain of shops and it operated the M.G. scheme by collecting premiums from its customers and then paying them over to M.G. V became concerned as a result of press reports that M.G. had not obtained proper insurance coverage for the scheme, and it negotiated with M.G. so as to protect the interests of its customers by safeguarding the money in the relevant M.G. account. To stave off proceedings for a Mareva injunction or

80. Supra. n.2 at 282.

81. [1982] A.C. 584. See also Re Multi Guarantee Co. Lid. infra. n.83.

82. [1926] A.C. 703 at $706-707$.

83. [ 1987] B.C.L.C. 257. See also Re Bank of Credit and Commerce International S.A. (No. 3) [1994] BCC 462 where the argument based on the alleged existence of a Quistclose type trust was very much a fall-back position and an unsuccessful one at that. 
for an order for the interim preservation of property, M.G. agreed to transfer the money into a joint deposit account which could only be drawn on under the joint signatures of M.G.'s and V's solicitors.

There were however no detailed terms concerning the basis on which withdrawals might be made from this ccount. $V$ succeeded in arranging its own insurance cover for the extended warranty protection, but before an agreement to release the money in the joint deposit account to $V$ could be effectuated, M.G. went into liquidation. The question before the court was whether as V contended, M.G. had constituted itself a trustee of the money in the account, and in this way divested itself of all beneficial interest therein.

The Court of Appeal held that M.G. had never displayed a sufficient intention to create a trust. ${ }^{84}$ The necessary certainty of intention had not been shown and thus the premium moneys constituted part of the general assets of M.G. The problem was that there were a number of possible destinations for the money in the joint account apart from being returned to $\mathrm{V}$. For instance it could have been paid directly to any one or more of a number of possible insurers.

On the other hand Re Multi Guarantee Co. Ltd. was distinguished and a trust held to have been established in Re Lewis's of Leicester Ltd. ${ }^{84 a}$ This is a case where a number of licensees occupied "shop within a shop" concessions in a department store. The licensees included those who sold their own goods but put the takings in the company's tills on standard terms which provided for them to receive from the company a payment equivalent to gross takings less returns and commission. The financial position of the company became parlous and it took steps to ensure that further receipts of licensees' takings, mistakenly believed to be already subject to a trust under the standard form agreements, were kept separate and identifiable in segregated accounts. Did this mistaken assumption vitiate the intention to establish a trust on the basis that if a person believes that he is a trustee he cannot logically intend to create a trust for the first time. Robert Walker J. refused to accept this prosposition. In his view there had been segregation of moneys and the incorrect false assumption was a fortiori a reason for holding that a trust had been brought into being.

\section{Certainty of subject-matter}

The property which is said to form the subject-matter of the alleged trust must be identifiable. A trust claim failed on this ground in Re London Wine Co (Shippers) $L t d .{ }^{85}$ This case involved a wine merchant who appropriated part of its general wine

84. See the statement by Nourse L.J. ibid. at 268.

84a. [1995] BCC 514.

85. [1986] P.C.C. 121. The case was decided on November 7, 1975. See also Export Credits Guarantee Dept. v. Turner 1981 S.L.T. 286. 
stock to a specific customer order only when the customer came to collect the wine. The wine merchant went into receivership. Oliver J. held that customers could not claim to be beneficiaries under a trust (of the wine) as the essential element of certainty of subject matter was absent.

Re London Wine Co (Shippers) Ltd. was distinguished in Hunter v Moss. ${ }^{85 a}$ In this case the defendant was the absolute beneficial owner of 950 shares in a company which had an issued share capital of 1,000 ordinary shares. He orally declared himself to be a trustee of these shares for the plaintiff. Was there the requisite certainty of subject matter for the trust to be effective? The Court of Appeal answered in the affirmative in this particular case, since all the shares were of one class in one company and were of such a nature as to be indistinguishable from one another. They were all equally capable of satisfying the trust. ${ }^{85 b}$

\section{Certainty of objects}

Even if the requirements of certainty of intention and certainty of subject-matter are satisfied, there cannot be a valid rust for beneficiaries or purposes if those beneficiaries or purposes are themselves insufficiently certain. ${ }^{86}$ In such a situation of uncertainty the property is held on a resulting trust for the settlor. The word "resulting" is used in the sense of "springing back"' ${ }^{87}$ The beneficial interest is said to spring back to the grantor but in reality it never left him. In Quistclose itself the primary purpose of the payment was held to have failed so that the property was held on a resulting trust for the grantor. ${ }^{88}$

85a. [1994] 3 All E.R. 215. See also Re Goldcorp Exchange Ltd. [1994] 2 All E.R. 806 and Re Stapylton Fletcher Ltd. [1995] i All E.R. 192.

85 b. Dillon L.J. said at 222 , "Just as a person can give, by will, a specified number of his shares of a certain class in a certain company, so equally, in my judgment, he can declare himself trustee of 50 of his ordinary shares in . . . whatever the company may be, and that is effective to give a beneficial proprietary interest to the beneficiary under the trust."

86. Generally the only type of valid purpose trusts are charitable trusts because of the beneficiary principle, i.e. there must be beneficiaries who can apply to the court to enforce their rights. In the case of a charitable trust the Attorney General, as guardian of the public interest, may enforce. However, the courts have recognised a certain anomalous category of non-charitable trusts. See generally Re Astor's Settlement Trusts [1952] Ch. 534; Leahy v. Attorney General for New South Wales [1959] A.C. 457; Re Denley's Trust Deed [1969] 1 Ch. 373 and Wicks v. Firth [1983] A.C. 214.

87. "Resulting" is derived from the Latin verb resalire.

88. There has been some discussion as to the nature of this secondary trust. In the Australian High Court case Australasian Conference Association Ltd. v. Mainline Constructions Pry. Ltd. (1979) 141 C.L.R. 335 at 353 Gibbs A.C.J. conceived of Quistclose as standing for the proposition that where money is advanced by $A$ to $B$ with the mutual intention that it should not become part of the assets of B, but should be used exclusively for a specific purpose, there will be implied, at least in the absence of a contrary intention, a stipulation that if the purpose fails the money will be repaid. In Quistclose, on the other hand, Lord Wilberforce seems to see the secondary trust as being based on an intention on the part of the lender. It was submitted that the controversy is a somewhat sterile one with the differences in formulation being more a matter of terminology than of substance. 


\section{Enforcement rights}

Controversy has dogged the Quistclose trust in relation to the right of the settlor, recognised in the locus classicus itself, to see that the property is applied for the primary stated purpose.$^{89}$ It has been suggested that the right is not the right of a beneficiary under the resulting trust, for if the primary purpose is fulfilled there is no resulting trust and the payer is a mere creditor. It is axiomatic that, as a general proposition, a grantor or settlor who retains no beneficial interest cannot enforce the trust which he has created, but the beneficiaries can. ${ }^{90}$ This principle forms the basis of the rule against non-charitable purpose trusts and also is at the heart of the principle enunciated in Saunders v. Vautier. ${ }^{91}$ Under this doctrine beneficiaries of full age and consent, who are all ascertained and between them entitled to the entire beneficial interest in the trust property, may have the property transferred to themselves absolutely, and bring the trust to an end.

Peter Millett Q.C., as he then was, has argued vehemently that Quistclose does not necessitate the recognition of a new genus of enforceable purpose trust which a settlor may enforce. ${ }^{92}$ In his opinion the question of enforceability involves an examination of the payer's intention, which is to be gleaned from the conduct of the parties, the language used and the circumstances of the case. Mr. Millett has suggested various guidelines by which the payer's intention may be ascertained. ${ }^{93}$ These guidelines were expressly adopted and applied by Hardie Boys J. speaking for the New Zealand Court of Appeal in General Communications Ltd. v. DFCNew Zealand Ltd:94

“1. If A's intention was to benefit C, or his object would be frustrated if he were to retain a power of revocation, the transaction will create an irrevocable trust in favour of $\mathrm{C}$, enforceable by $\mathrm{C}$, but not by $\mathrm{A}$. The beneficial interest in the trust property will be in $C$.

2. If A's intention was to benefit $B$ (though without vesting a beneficial interest in him), or to benefit himself by furthering some private or commercial interest of his own, and not (except incidentally) to benefit $\mathrm{C}$, then the transaction will

89. See Heydon, Gummow and Austin, at 357; Millett, supra.n.8 at 287.

90. This principle forms the basis of the rule against non-charitable purpose trusts and also is at the heart of the doctrine enunciated in Saunders v. Vautier infra. 91 and text.

91. (1841) Cr. \& Ph. 240.

92. Supra. n. 8 particularly at p. 290 . Mr. Millett is now a Judge.

93. Ibid. at 290. These guidelines were adopted and applied by Hardie Boys J. speaking for the New Zealand Court of Appeal in General Communications Ltd v. DFC New Zealand Ltd. [1990] 3 N.Z.L.R. 406. For critical comment see Rickett, supra. n.l at 630 et seq. Other New Zealand cases include Dines Construction Ltd. v. Perry Dines Corp Ltd. (1989) 4 N.Z.C. L C. 65, and Re Securitibank Ltd. [1978] 1 N.Z.L.R. 97 and more recently Lankshear v. A.N.Z. [1993] I N.Z.L.R. 481. Relevant Australian authority includes Re Associated Securities Lrd. [1981] 1 N.S.W.L.R. 742; Rose v. Rose (1986) 7 N.S.W.L.R. 679; Re Groom (1977) 16 ALR 278; Re Miles (1989) 85 ALR 216.

94. [1990] 3 N.Z.L.R. 406 at 432-433. See also Dines Construction Ltd. v. Perry Dines Corp. Lrd. ibid. at p. 298. The New Zealand cases are discussed by Rickett, supra. $\mathrm{n} .1$ at $630-646$, and see also J.K. Maxton, "Quistclose Developments in New Zealand" (1990) 9 Int. Banking Law 216. 
create a trust in favour of $\mathrm{A}$ alone, and B will hold the trust property in trust to comply with A's directions. The trust will be enforceable by A but not by C. The beneficial interest will remain in $A$.

3. Where A's object was to save B from bankruptcy by enabling him to pay his creditors, the prima facie inference is that set out in paragraph 2 above. Wherever that is the correct inference;

(i) Where A has an interest of his own, separate and distinct from any interest of $B$, in seeing that the money is applied for the stated purpose, B will be under a positive obligation, enforceable by $\mathrm{A}$, to apply it for that purpose. Where $\mathrm{A}$ has no such interest, B will be regarded as having a power, but no duty, to apply it for the stated purpose, and A's remedy will be confined to preventing the misapplication of the money.

(ii) Prima facie, A's directions will be regarded as revocable by him; but he may contract with B not to revoke them without B's consent.

(iii) Communication to $C$ of the arrangements prior to $A$ 's revocation will effect an assignment of $A$ 's equitable interest to $C$, and convert $A$ 's revocable mandate into an irrevocable trust for C."

The New Zealand Court of Appeal entered one caveat. Millett's formulation suggested that it was the lender's intention that was relevant, whereas in Quistclose the emphasis was on mutual intention. ${ }^{95} \mathrm{~A}$ reconciliation was suggested on the basis that intention had to be ascertained objectively. ${ }^{96}$ What one party was objectively seen to have intended must, ex hypothesi, have been appreciated by the other and accepted by him when he participated in the arrangement.

General Communications Ltd. involved in acute form, the issue of the resolution of the following conundrum. A lender, $\mathrm{A}$, lends money to $\mathrm{B}$, with the latter undertaking that the money shall be applied for the purpose of paying off his creditor, $\mathrm{C}$. Is the creditor entitled to recover what he was given to understand was intended for him, but was not paid, having instead been reclaimed by the lender? The Court said "yes" but only because of the peculiar circumstances of the case rather than by reason of the adoption of any general principle. While the guidelines propounded by Mr. Millett were clearly accepted, their manner of application is somewhat ambiguous. Stress was laid on the fact that the arrangements had been communicated to the creditor, $\mathrm{C}$, making it clear that the latter need not rely on B alone for payment. This would indicate a category 3 (iii) case. ${ }^{97}$ On the other hand, the Court also said that as the purpose of the arrangement would be defeated by the lender, $\mathrm{A}$ being able to revoke

95. Lord Wilberforce said that the mutual intention of the respondents and of Rolls Razor Ltd., and the essence of the bargain, was that the sum advanced should not become part of the assets of Rolls Razor Ltd. but should be used exclusively for payment of a particular class of its creditors, namely those entitled to the dividend: see supra. n.3 at 580 .

96. Supra. n.93 at 433.

97. Ibid. at 435 . 
it at will, it had put the funds beyond its power of recall and had conferred a beneficial interest on each supplier as each contract of supply was fulfilled..$^{98}$ This exposition would seem to suggest a category 1 classification.

Mr. Millett's analysis views the Quistclose trust as an example of what is sometimes called an "illusory trust." "99 Where a valid trust has been brought into being it cannot be revoked by the settlor unless the settlement itself contains a power of revocation. Where a debtor conveys property for the benefit of his creditors an exception to the principle of non-revocability is said to arise, but the true view seems to be that the apparent beneficiaries never acquire any interest in the property at all. All we have is a trust to comply with the settlor's directions. ${ }^{100}$ According to one judge:

"A man who, without any communication with his creditors, puts property into the hands of his trustees for the purpose of paying his debts, proposes only a benefit for himself by the payment of his debts: his object is not to benefit his creditors." 101

\section{According to James L.J. in John v. James:}

"Such a deed as this is to be construed as a mandate, the same sort of mandate that a man gives when he gives his servant money, with directions to pay it in a particular way: it does not create any legal or equitable right in favour of a particular creditor. The right to the direction of the money is the right of the person who has put the money in the hands of his agent or steward or whoever it may be." 102

\section{English unorthodoxy}

The issue of enforceability of a Quistclose trust was considered in Carreras Rothmans Ltd. v. Freeman Mathews Treasure Ltd. Peter Gibson J. pointed out that in none of the many reported cases in the Quistclose line of cases had any consideration been given to the question, whether the person intended to benefit from the carrying out of the specific purpose which created the trust, had enforceable rights. ${ }^{103}$ In this case he rejected the proposition that the third party creditors, for the payment of whose debts the plaintiff had paid the moneys into the special account, had no enforceable

98. Ibid. The court said that there was not the intention to confer a direct and immediate benefit that marked New Prance \& Garrard's Trustee v. Hunting [1897] 2 Q.B. 19. This is a case where a trust was established to make good to their beneficiaries breaches of other trusts by the settlor, who intended to give them an absolute interest. Lord Esher M.R. said at p.26 that it was "obvious that it could not be his intention to reserve to himself any right or possibility of undoing what he was doing, and that he intended that it should be irrevocable".

99. Supra. n. 8 at $288-289$.

100. See generally on illusory trusts Pettit, Equity and the Law of Trusts (7th. ed. 1993) at pp. 214-215. 101. Pepys M.R. in Bill v. Cureton (1834) 2 My. \& K. 503 at 511.

102. (1878) 8 Ch. D. 744 at $749-750$.

103. Supra. n.28. 
rights. He also said that the doctrine of illusory trusts had no application to the facts of the present case. ${ }^{104}$

Copious reference was made in the case to the unreported decision of Sir Robert Megarry V.C. in Re Northern Developments (Holdings) Ltd. ${ }^{105}$ This is a case where one company, Northern, was the parent company of a number of companies including one, Kelly, that was in financial difficulties. A consortium of banks agreed to put up a large sum of money in an attempt to rescue Kelly. This money was used to keep Kelly alive for a time, but Kelly was then put into receivership at a time when more than half the fund was unexpended. The Vice Chancellor held that the fund was subject to a Quistclose type trust. This trust was enforceable by the bank as lenders, by Kelly for whose immediate benefit the fund was established, and by Kelly's creditors. The interests of creditors were described in the following fashion:

"The fund was established not with the object of vesting the beneficial interest
in them, but in order to confer a benefit on Kelly (and so, consequentially, on
the rest of the group and the bankers) by ensuring that Kelly's creditors would
be paid in an orderly manner. There is perhaps some parallel in the position
of a beneficiary entitled to a share of residue under a will. What he has is not
a beneficial interest in any asset forming part of residue, but a right to compel
the executor to administer the assets of the deceased properly. It seems to me
that it is that sort of right which the creditors of Kelly had."

On this interpretation the beneficial interest is in suspense until the payment is made. Mr. Millett argues that the right result was reached in Re Northern Developments (Holdings) Ltd. but for the wrong reasons. ${ }^{106} \mathrm{He}$ relies on the fact that creditors of Kelly were aware of the existence of the fund and derived comfort from its existence. It seems that creditors of Kelly who applied for payment of their debts or who expressed concern were told of the existence, size and purpose of the fund i.e. to stave off a liquidation of Kelly. In Mr. Millett's view communication of the arrangements to the creditor, followed by forebearance by the creditor, raises an equity against the payer which prevents him from revoking the arrangements, or otherwise intercepting payment to the creditor. Be that as it may, it is certainly not the way in which Megarry V.C. approached the case. It is submitted that the following statement by one commentator more truly reflects the principles expounded in the English cases on the Quistclose trust:

104. According to Peter Gibson J. the doctrine of illusory trusts applied where a debtor for his own convenience settled property in favour of his creditors, the court treating the trust as a revocable one. In the present case although the defendant agreed to the discharge of an asset, its book debts, by payment by its debtor, the plaintiff, in such a way that the moneys paid would not be held on trust to pay its creditors, the defendant did not enter into the arrangement for its convenience but for good commercial reasons on the insistence of the plaintiff and the trust was not for its creditors generally but for a particular class of creditor.

105. Supra. n.16.

106. Supra. n.8. 
"A variety of equitable rights and obligations arise in respect of the primary purpose trust:

(i) the transferor can enforce the trust, and it is suggested, restrain any breach of the trust on the part of the transferee;

(ii) the "direct" or "factual" beneficiaries can also enforce the trust, so as to acquire by the transfer of the money or property to them an absolute title, and, it is suggested, can also restrain any breach of the trust;

(iii) certain other 'interested parties' might be treated as having standing also to enforce or restrain breaches, e.g. subsidiary companies where the transferee is the parent company and the transfer was made in the context of a corporate salvage plan.

While the primary purpose trust endures, the beneficial interest in the property remains in suspense." 107 .

\section{Conclusion}

Conditional payments made to a company that has subsequently become insolvent should escape the clutches of the liquidator. The devices through which this result can be achieved are discussed in this article. The Quistclose trust is one such mechanism and the $R e$ Kayford type trust is another. Quistclose involves a primary purpose/secondary purpose trust whereas the Re Kayford line of authorities entail more in the nature of an orthodox persons trust with specific and recognisable beneficiaries, and no added complication of a secondary purpose. Here both have been run together under the rubric of conditional payments since they serve the same commercial purpose. Both strain at the leash of conventional trust principles. With the Quistclose trust the difficulty lies with the application of the beneficiary concept which is at the heart of trust law. It is submitted however that the problems may be overcome if the relevant principles are interpreted flexibly, and bearing in mind the overriding commercial objective of conditional payment arrangements. The Quistclose trust is the functional equivalent of the purchase money security interest or acquisition mortgage and should be accorded recognition and priority as such. ${ }^{108}$. With Re Kayford and associated cases the difficulties arise at an altogether more factual level. Sometimes the conditional element in the payment may seem like an exercise in ex post facto rationalisation and the decision approaches an application of discretionary justice. If that is the case then we are more in the realm of the so-called remedial constructive trust - but that is another story.

107.See Rickett supra. n.1 at 619. The article by Rickett also contains an interesting account of the Australian cases Re Groom; Re Associated Securities Lid; Rose v. Rose; and Re Miles all supra. n.93.

108. For the use of the concept of the purchase money security interest in a different context see Bennett and Davis, (1994) 110 L.Q.R. 448. 